\title{
Low prevalence of byssinotic symptoms in 12 flax scutching mills in Normandy, France
}

\author{
F F CINKOTAI, ${ }^{2}$ P EMO,${ }^{2}$ A C C GIBBS, ${ }^{3}$ J-F CAILLARD, ${ }^{2}$ J-M JOUANY ${ }^{2}$
}

From the Department of Occupational Health,' University of Manchester, Hôpital Charles-Nicolle, ${ }^{2}$ Centre Hospitalier Regional and Universitaire de Rouen, Rouen, Normandy, France, and Department of Community Medicine, ${ }^{3}$ University of Manchester, Manchester, UK

ABSTRACT The concentrations of airborne dust and bacteria were determined in 12 flax scutching mills and in two milk processing plants in Normandy, France. A total of 308 of 340 flax workers and 111 of 113 milk processors volunteered to answer a respiratory questionnaire. Personal exposure to airborne dust in the scutching mills varied from $22.2 \mathrm{mg} / \mathrm{m}^{3}$ to $144 \mathrm{mg} / \mathrm{m}^{3}$ and areal concentrations from $8.92 \mathrm{mg} / \mathrm{m}^{3}$ to $47.1 \mathrm{mg} / \mathrm{m}^{3}$. The concentration of Gram negative bacteria ranged from 3970 (colony forming units) $\mathrm{cfu} / \mathrm{m}^{3}$ to $67900 \mathrm{cfu} / \mathrm{m}^{3}$ and that of total bacteria from $12900 \mathrm{cfu} / \mathrm{m}^{3}$ to more than $600000 \mathrm{cfu} / \mathrm{m}^{3}$. In all, $20 \%$ of the flax scutchers were found, on the basis of the questionnaire, to suffer from persistent cough and $25 \%$ from chronic phlegm production. The corresponding figures among milk processors were $3 \cdot 6 \%$ and $4.5 \%$. Unexpectedly, only $12 \cdot 5 \%$ of the scutchers appeared to suffer from byssinotic symptoms even though they were heavily exposed to airborne dust and bacteria. The low prevalence of byssinosis might be due to self selection of the workforce or a relatively low concentration of the causative agent despite high airborne contamination.

People working in mills processing water and dew retted flax have repeatedly been found to suffer from general respiratory symptoms including those of byssinosis. $^{1-5}$ Elwood et al in Northern Ireland ${ }^{6}$ and Noweir et al in Egypt ${ }^{7}$ observed some correlation between airborne dust and the prevalence of byssinosis and on the basis of these findings and other considerations, a control limit of $2 \mathrm{mg} / \mathrm{m}^{3}$ was established in Britain. ${ }^{8}$ A high prevalence of byssinotic symptoms was not, however, universally observed in all factories processing retted flax. An example is the flax industry in Normandy, France, which forms the subject matter of the present study [J-F Caillard, unpublished observation).

The flax industry in Normandy includes numerous independent scutching plants that use locally grown, dew retted flax and employ hundreds of people. The plants are invariably small; the machinery tends to be old and dust suppression devices are frequently absent. Consequently, the processes are extremely dusty. Nevertheless, past respiratory surveys of the industry have not shown any workers who might have suffered from byssinosis (J-F Caillard, unpublished

Accepted 29 June 1987 observation), although numerous workers were afflicted with persistent cough and chronic phlegm production. The purpose of the present study was to investigate this anomaly.

\section{Method}

Twelve scutching plants were surveyed, each of which housed two to four scutching lines: two milk processing plants were used as controls. Bales of dry, retted flax were opened and fed manually into the scutching line at one end and the free fibres leaving the line at the other end were gathered into bundles, also by hand, and compressed into bales in presses. Normally noone worked between the two ends of a line. The plants were neither heated nor humidified. The milk processing plants were spotlessly clean and free of airborne contamination, therefore no dust or bacteria measurements were performed.

Only workers who spent at least half their worktime inside the scutching plant were asked to answer a French translation of a specially modified version of the British Medical Research Council respiratory symptoms questionnaire used previously in Lancashire textile mills. The questions were asked by one of us from a "lap top" microcomputer (Tandy TRS80, 
model 100) programmed to display the questions and to store the answers which were subsequently transferred to the memory file of a main-frame computer for statistical analysis. The questionnaire was designed (a) to determine some personal details such as work experience, smoking habit, and physical fitness and $(b)$ to establish whether or not a person suffered from persistent cough, chronic phlegm production, or both-that is, chronic bronchitis, byssinosis, asthma, occupational asthma, or humidifier fever.

Within a few weeks of the initial questionnaire survey in the flax scutching plants, a supplementary survey was carried out because it was thought that the questions concerning the byssinotic syndrome in the initial survey might not have been sufficiently precise. The supplementary questions asked were designed to establish whether or not people experienced any respiratory discomfort after returning to work from a long leave (a holiday, for example), the nature and duration of discomfort, and whether or not this occurred in general also during the first workshift after a weekend.

The concentration of airborne dust in the workzone was measured at two points at the front end of the line where the raw material was fed in and at two points at the back end where the free fibres left. The RotheroeMitchell L60 pump placed on a $1.5 \mathrm{~m}$ stand was used to collect the samples. Three volunteers at each end of the line wore the Casella AFC 123 personal sampling pumps and heads for measuring the concentration of airborne particles in the subjects' breathing zone. All sampling instruments were operated for at least six hours of a workshift and the samples were collected on glass fibre filters $(26 \mathrm{~mm}$ for the areal samplers and $18 \mathrm{~mm}$ for the personal samplers) which were dried and weighed on a Cahn electromicrobalance both before and after sampling. Flow rates through the sampling heads were frequently checked and the filter papers frequently changed to avoid the accumulation of an excessively thick layer of dust on the filter.

Airborne Gram negative and total bacteria were sampled by means of the Andersen viable sampler at points where the workzone dust samples were collected. The airborne dust including the microbes was impacted into petrie dishes containing either a nutrient agar medium for growing any bacterium or an endoagar medium (including 0.5 units $/ \mathrm{ml}$ penicillin) for selectively growing Gram negative organisms. The plates were then incubated for 24 hours at $36^{\circ} \mathrm{C}$ and for a second period of 24 hours at room temperature. Counts of colony forming units (cfu) were corrected as recommended by the manufacturer. Two sets of samples were collected at each sampling point and because of the high concentrations observed, the sampling duration at any one time had to be limited to 30 seconds for Gram negative bacteria and to five seconds for the total bacteria; otherwise the plates would have been grossly overexposed.

\section{Results}

Of the 340 people employed to operate the scutching lines, $308(91 \%)$ answered the respiratory symptom questionnaire, nine refused, and 20, comprising an entire shift, were not asked due to lack of time. Of those interviewed, all but three were men: 133 had been employed in the industry for longer than two years but less than 10 years, 98 had been employed for longer than 10 years, $173(56 \%)$ were smokers, and 55 $(18 \%)$ were ex-smokers (table 1). In the supplementary

Table 1 Distribution of the people interviewed according to years of work experience in the flax industry, smoking habit, and presence of persistent cough, chronic phlegm production, and byssinotic symptoms (column a represents the number of people who claimed to suffer from byssinotic symptoms in the initial survey and column b the number in the supplementary survey) in 12 flax scutching mills and two milk processing plants (controls)

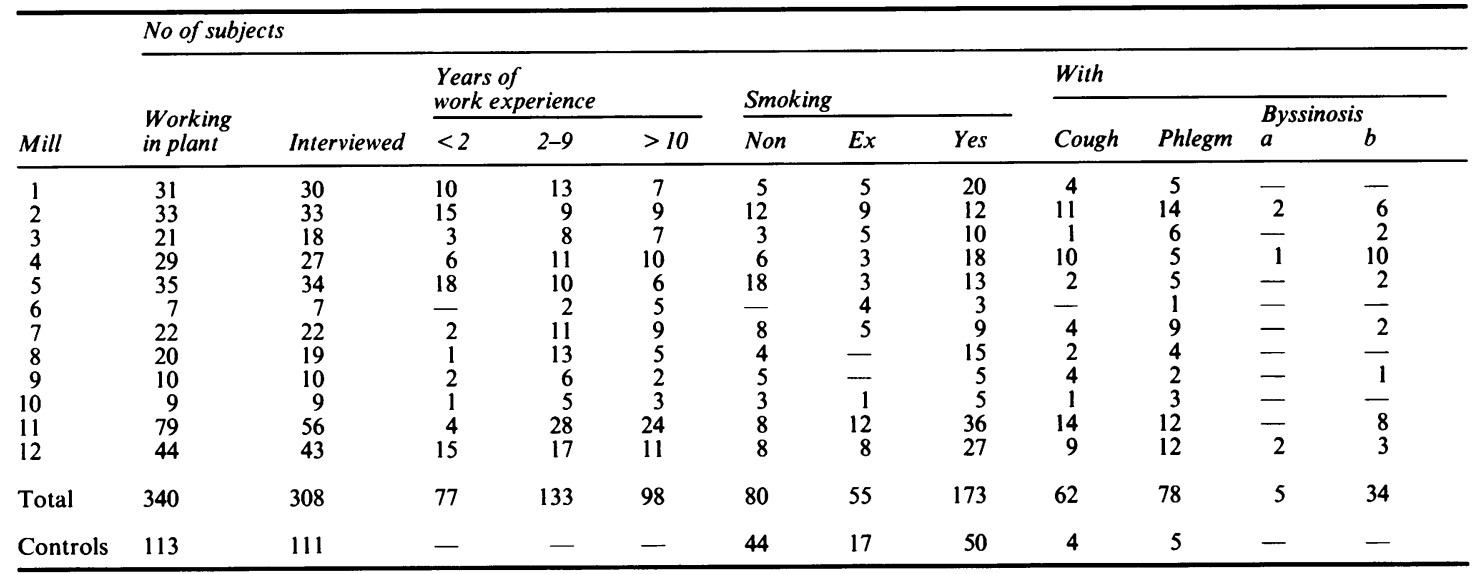


Table 2 Concentration of airborne dust $\left(\mathrm{mg} / \mathrm{m}^{3}\right)$ in the workers' personal breathing zone (PBZ) and that of airborne dust and Gram negative and total bacteria $\left(\mathrm{cfu} / \mathrm{m}^{3}\right)$ in the workzone (WZ). (No indicates the number of concurrent samples collected in each factory)

\begin{tabular}{|c|c|c|c|c|c|c|c|c|c|c|c|}
\hline \multirow[b]{3}{*}{ Mill } & \multicolumn{6}{|c|}{ Dust concentration in } & \multicolumn{5}{|c|}{ Bacteria concentration in $W Z$} \\
\hline & \multicolumn{3}{|c|}{$P B Z$} & \multicolumn{3}{|l|}{$W Z$} & \multicolumn{3}{|c|}{ Gram negative } & \multicolumn{2}{|c|}{ All organisms } \\
\hline & No & $\begin{array}{l}\text { Mean } \\
\quad\left(\mathrm{mg} / \mathrm{m}^{3}\right)\end{array}$ & $S D$ & No & $\begin{array}{l}\text { Mean } \\
\quad\left(\mathrm{mg} / \mathrm{m}^{3}\right)\end{array}$ & $S D$ & No & $\begin{array}{l}\text { Mean } \\
\text { (cfu/m }\end{array}$ & $S D$ & $\underset{(c f u / r}{M e a n}$ & $\begin{array}{l}S D \\
\left.10^{s}\right)\end{array}$ \\
\hline $\begin{array}{r}1 \\
2 \\
3 \\
4 \\
5 \\
6 \\
7 \\
8 \\
9 \\
10 \\
11 \\
12\end{array}$ & $\begin{array}{l}6 \\
6 \\
6 \\
6 \\
6 \\
5 \\
6 \\
6 \\
6 \\
6 \\
6 \\
6\end{array}$ & $\begin{array}{c}17 \cdot 1 \\
110 \\
39 \cdot 6 \\
53 \cdot 9 \\
30 \cdot 7 \\
22 \cdot 2 \\
91 \cdot 2 \\
39 \cdot 6 \\
87 \cdot 4 \\
98 \cdot 5 \\
144 \\
67 \cdot 3\end{array}$ & $\begin{array}{c}12 \cdot 6 \\
67 \cdot 6 \\
25 \cdot 4 \\
52 \cdot 0 \\
18 \cdot 7 \\
9 \cdot 80 \\
24 \cdot 5 \\
33 \cdot 1 \\
107 \\
84 \cdot 6 \\
175 \\
40 \cdot 8\end{array}$ & $\begin{array}{l}3 \\
4 \\
4 \\
4 \\
4 \\
4 \\
4 \\
4 \\
4 \\
4 \\
4 \\
4 \\
4 \\
4\end{array}$ & $\begin{array}{c}12 \cdot 6 \\
30 \cdot 6 \\
20 \cdot 6 \\
8 \cdot 92 \\
21 \cdot 1 \\
10 \cdot 7 \\
38 \cdot 1 \\
28 \cdot 3 \\
23 \cdot 1 \\
21 \cdot 1 \\
47 \cdot 1 \\
41 \cdot 5\end{array}$ & $\begin{array}{c}16 \cdot 7 \\
19 \cdot 8 \\
8 \cdot 37 \\
4 \cdot 41 \\
13 \cdot 0 \\
5 \cdot 65 \\
20 \cdot 9 \\
23 \cdot 0 \\
18 \cdot 1 \\
9 \cdot 41 \\
38 \cdot 1 \\
14 \cdot 1\end{array}$ & $\begin{array}{l}3 \\
4 \\
4 \\
4 \\
4 \\
4 \\
4 \\
4 \\
4 \\
4 \\
4 \\
4 \\
4 \\
4\end{array}$ & $\begin{array}{c}4 \cdot 75 \\
7 \cdot 05 \\
5 \cdot 68 \\
4 \cdot 47 \\
10 \cdot 2 \\
3.97 \\
67 \cdot 9 \\
14 \cdot 3 \\
54 \cdot 7 \\
11 \cdot 7 \\
4 \cdot 28 \\
37 \cdot 5\end{array}$ & $\begin{array}{c}3 \cdot 16 \\
6 \cdot 17 \\
5 \cdot 15 \\
2.96 \\
12 \cdot 1 \\
1 \cdot 63 \\
80 \cdot 3 \\
7 \cdot 97 \\
41 \cdot 0 \\
11 \cdot 2 \\
3 \cdot 23 \\
21 \cdot 1\end{array}$ & $\begin{array}{c}4.21 \\
>2.47 \\
>1.53 \\
1.29 \\
1.41 \\
2.06 \\
>54.8 \\
>20.7 \\
>61.1 \\
>23.0 \\
1.48 \\
>42.0\end{array}$ & $\begin{array}{cl} & 0.248 \\
> & 1.36 \\
> & 1.72 \\
& 1.52 \\
& 1.28 \\
& 0.900 \\
> & 1.50 \\
> & 13.7 \\
> & 52.9 \\
> & 5.29 \\
& 0.865 \\
> & 9.51\end{array}$ \\
\hline
\end{tabular}

survey 271 of the original 308 scutchers answered the questions; the remaining 37 were unavailable. Of 113 people approached in the milk processing plants, 111 answered the questionnaire; two were women, 50 $(45 \%)$ were smokers, $17(15 \%)$ were ex-smokers, 44 $(40 \%)$ were non-smokers, and none had ever been exposed to flax or any other dust for appreciable periods (table 1).

The concentration of airborne dust in the workzones of the flax scutching plants (time weighted arithmetic mean) ranged, on average, from $8.92 \mathrm{mg} / \mathrm{m}^{3}$ to $47.1 \mathrm{mg} / \mathrm{m}^{3}$ and in workers' personal breathing zones from $17 \cdot 1 \mathrm{mg} / \mathrm{m}^{3}$ to $144 \mathrm{mg} / \mathrm{m}^{3}$. As expected, the front end of the line where the dried but retted flax plant was fed in was considerably more dusty than the back end yielding the free fibre (table 2). The concentration of Gram negative organisms in workzones varied from $4280 \mathrm{cfu} / \mathrm{m}^{3}$ to $67900 \mathrm{cfu} / \mathrm{m}^{3}$ and that of the total bacteria from $141000 \mathrm{cfu} / \mathrm{m}^{3}$ to over $600000 \mathrm{cfu} / \mathrm{m}^{3}$.

The questionnaire survey indicated that $62(20 \%)$ of the flax workers suffered from persistent cough (coughing for at least three months of the year) and 78 $(25 \%)$ from chronic phlegm production (producing phlegm for at least three months of the year). Four $(3.6 \%)$ of the control population indicated that they suffered from persistent cough and five $(4.5 \%)$ from chronic phlegm production. The Mantel Haenszel chisquared procedure was used to compare the prevalence of these symptoms in flax scutchers and milk processors. This was made by grouping the data according to smoking habit expressed in pack years. ${ }^{9}$

Differences of persistent cough $(p<0.0001)$ and chronic phlegm production $(p<0.005)$ between the two groups of workers were highly significant. In the initial survey only five flax workers were found to suffer from symptoms similar to those of byssinosis (chest tightness or breathlessness, or both, on the first day of the workweek or on subsequent days, or both), 14 from symptoms similar to asthma, and four from symptoms resembling humidifier fever, whereas three subjects in the control population suffered from asthma like symptoms. In the supplementary survey 34 of the 271 interviewees $(12 \cdot 5 \%)$ had byssinotic symptoms.

The ages of those who suffered from respiratory symptoms, their duration of employment in the industry, and exposure to airborne dust and bacteria did not differ significantly from those who were symptom free. Persistent coughers and chronic phlegm producers did, however, use significantly more tobacco, and for longer periods, than those who did not suffer from these symptoms $(p<0.005)$ and sufferers from byssinosis tended to have worked in the industry longer than non-byssinotic workers $(p<0.02)$.

\section{Discussion}

A weakness of the present study lies in the translation of the questionnaire into French, even though a great deal of care was taken. The phrase "chest-tightness" may not have been accurately reproduced and this could have been the reason why only five of the 308 people in the initial survey appeared to suffer from byssinotic symptoms. Of the 271 scutchers reinterviewed, the 34 who responded positively to the supplementary questionnaire described a condition not dissimilar to grade $1 / 2$ or grade 1 byssinosis - that is, respiratory discomfort/breathlessness during the first workshift after a leave of absence or the weekend either occasionally (grade 1/2) or regularly (grade 1). None of these scutchers experienced the above symptoms during subsequent workshifts (grade 2).

Assuming that the supplementary survey showed all 
Table 3 Mean concentrations of airborne contaminants at the two ends of scutching lines in the flax scutching mills studied

\begin{tabular}{|c|c|c|c|c|}
\hline \multirow{2}{*}{$\begin{array}{l}\text { Airborne } \\
\text { contaminant }\end{array}$} & \multicolumn{2}{|l|}{ Front end } & \multicolumn{2}{|l|}{ Back end } \\
\hline & Mean & $S D$ & Mean & $S D$ \\
\hline $\begin{array}{l}\text { Dust in personal } \\
\text { breathing zone }\left(\mathrm{mg} / \mathrm{m}^{3}\right)\end{array}$ & 93.5 & $57 \cdot 6$ & $30 \cdot 5$ & $20 \cdot 0$ \\
\hline $\begin{array}{l}\text { Dust in workzone } \\
\left(\mathrm{mg} / \mathrm{m}^{3}\right)\end{array}$ & $36 \cdot 8$ & $21 \cdot 6$ & $16 \cdot 5$ & $10 \cdot 2$ \\
\hline $\begin{array}{l}\text { Gram negative bacteria in } \\
\text { workzone }\left(\mathrm{cfu} / \mathrm{m}^{3}\right)\end{array}$ & 2660 & 3810 & 1130 & 989 \\
\hline $\begin{array}{l}\text { Total bacteria in } \\
\text { workzone }\left(\mathrm{cfu} / \mathrm{m}^{3}\right)\end{array}$ & $1.91 * 10^{6}$ & $2 \cdot 39 * 10^{6}$ & $1 \cdot 69^{*} 10^{6}$ & $1.97 * 10^{6}$ \\
\hline
\end{tabular}

cfu $=$ Colony forming units.

true cases of byssinosis, the prevalence of byssinotic symptoms among Normandian flax scutchers even at the above rate $(12.5 \%)$ was small compared with the $54 \%$ observed in Northern Ireland ${ }^{10}$ or $37 \%$ in Egypt. ${ }^{7}$ This is unexpected in view of the fact that scutchers in this survey have been exposed to extraordinarily high concentrations of airborne dust and bacteria.

Some evidence suggests that when the concentration of airborne dust is excessively high in a cotton mill the prevalence of byssinotic symptoms declines. ${ }^{112}$ The cause of this phenomenon is not understood, but some researchers have proposed that self selection among the workforce might account for it. Newcomers to the industry whose respiratory system reacts to the contamination too severely leave at once, probably never to return. The flax scutching plants in our study were certainly extremely heavily contaminated and could be a case in point. Furthermore, persistent severe coughing and chronic phlegm production as observed may prevent a person from being aware of his/her byssinotic symptoms. Certainly the association between byssinotic symptoms and persistent cough or chronic phlegm production was highly significant (chi-squared $>8.2$, df $=1, p<0.004)$ as has been observed before. ${ }^{10}$ Alternatively, even though airborne contamination is high, the agent(s) that cause(s) byssinotic symptoms, be it a particular strain of micro-organism or some vegetable matter, may occur in a flax scutching plant in lower concentrations than in some cotton spinning mills. The concentration of airborne endotoxins was not determined in the present study but would have probably been extremely high. Thus the low prevalence of byssinotic symptoms observed would seem to concur with the findings of Jamison and Lowry that exposure to endotoxins is not necessarily associated with byssinotic symptoms. ${ }^{13}$

Although exposure to airborne dust or bacteria did not differ significantly for workers with or without byssinotic symptoms, the association between persistent cough or chronic bronchitis and the concentration of airborne dust measured in the workzone was statistically significant (chi-squared $>4 \cdot 5$, df $=1$, $p<0.05)$ as was that between chronic bronchitis and the concentration of airborne Gram negative bacteria (chi-squared $>4.2, \mathrm{df}=1, \mathrm{p}<0.05$ ) and between persistent cough or chronic bronchitis and the subjects' trade (chi-squared $>18.2, \mathrm{df}=7, \mathrm{p}<0.025$ ). These associations showed, not unexpectedly, a tendency among those who worked at the dustier end of the scutching line to suffer from chronic bronchitis. Variability in the concentration of airborne contaminants was, however, far too high to allow the detection of any other relation (table 3). Therefore it cannot rightly be inferred from the present observations that flax dust or bacteria are not in some way associated with byssinosis.

That airborne dust and bacteria in a flax scutching mill is toxic is clearly indicated when prevalences of persistent cough $(20 \%)$ and chronic phlegm production $(25 \%)$ in flax scutching mills are compared with those in milk processing plants $(3.6 \%$ and $4.5 \%)$ which are free from airborne contaminants.

This study was sponsored by the British Cotton Growing Association Ltd Work People's Collection Fund. We are grateful to the workers and managements of the agricultural cooperatives for their unreserved hospitality and participation and the Association de Medicine du Travail en Agriculture de Seine-Maritime for help and cooperation.

\section{References}

1 Mair A, Smith DH, Wilson WA, Lockhart W. Dust diseases in Dundee textile workers. An investigation into chronic respiratory disease in jute and flax industries. $\mathrm{Br} J$ Ind Med 1960;17:272-8.

2 Bouhuys A, Hartogensis F, Korfage HJH. Byssinosis prevalence and flax processing. Br J Ind Med 1963;20:320-3.

3 El Batawi MA, Hussein M. Endemic byssinosis in an Egyptian village. Br J Ind Med 1964;21:231-4.

4 Carey GCR, Elwood PC, McAulay IR, Merrett JD, Pemberton J. Byssinosis in flax workers in Northern Ireland. Belfast: HMSO. 1965.

5 Valic F, Zuskin E. Effects of different vegetable dust exposures. $\mathrm{Br}$ $J$ Ind Med 1972;29:293-7.

6 Elwood PC, McAulay IR, McLarin RH, Pemberton J, Carey GCR, Merrett JD. Prevalence of byssinosis and dust levels in flax preparers in Northern Ireland. $\mathrm{Br} J$ Ind Med 1966; 23:188-93.

7 Noweir MH, El-Sadik YM, El-Dakhakhny AZ, Osman HA. Dust exposure in manual flax processing in Egypt. Br $J$ Ind Med 1975;32:147-54.

8 BOHS Committee on Hygiene Standard: Sub-Committee on Vegetable Textile Dusts. A basis for hygiene standard for flax dust. Ann Occup Hyg 1980;23:1-26.

9 Fliess JL. Statistical methods for rates and proportions. 2nd ed. New York: Wiley, 1981:173-5.

10 Elwood PC, Pemberton J, Merrett JD, Carey GCR, McAulay IR. Byssinosis and other respiratory symptoms in flax workers in Northern Ireland. Br J Ind Med 1965;22:27-37.

11 Merchant JH, Lumsden JC, Kilburn KH, et al. Dose response studies in cotton textile workers. J Occup Med 1973;15:222-30.

12 Chinn DJ, Cinkotai FF, Lockwood MG, Logan SHM. Airborne dust, its protease content and byssinosis in "willowing" mills. Ann Occup Hyg 1976;19:101-8.

13 Jamison JP, Lowry RC. Bronchial challenge of normal subjects with the endotoxin of enterobacter agglomerans isolated from cotton dust. Br J Ind Med 1986;43:327-31. 